\title{
Sibling species of copepods in association with Mediterranean gorgonians*
}

\author{
MERCEDES CONRADI ${ }^{1}$, CÉSAR MEGINA² ${ }^{2}$ and PABLO J. LÓPEZ-GONZÁLEZ ${ }^{1}$ \\ ${ }^{1}$ Biodiversidad y Ecología de Invertebrados Marinos, Departamento de Fisiología y Zoología, Facultad de Biología. \\ Universidad de Sevilla. Reina Mercedes 6, 41012 Sevilla, Spain. E-mail: mconradi@us.es / pjlopez@us.es \\ ${ }^{2}$ Departamento de Biología Animal, Vegetal y Ecología, Facultad de Ciencias del Mar. Universidad de Cádiz. \\ Polígono Rio San Pedro, s/n, 15010
}

\begin{abstract}
SUMMARY: Hitherto a single species of Doridicola Leydig (Poecilostomatoida: Rhynchomolgidae) has been found reported in association with gorgonians in Europe: Doridicola botulosus (Stock and Kleeton, 1963), living on the Mediterranean gorgonian Eunicella singularis (Esper, 1791). During a survey along the Iberian Mediterranean coast, several specimens of D. botulosus were collected from its reported host. Furthermore, an undescribed species of Doridicola was discovered living in association with Paramuricea clavata (Risso, 1826), a Mediterranean gorgonian usually living in overlaps with that of E. singularis. Although the new species is close to D. botulosus, they differ in the oral appendages. A common origin of these two species was suggested. This is a good example of sibling species produced by the colonisation of two hosts with overlapping habitats.
\end{abstract}

Key words: Mediterranean, octocorals, Copepoda, symbiosis, speciation, new species.

RESUMEN: ESPECIES GEMELAS DE COPEPODOS ASOCIADOS A GORGONIAS MEDITERRÁNEAS. - Hasta el momento una sola especie de Doridicola Leydig (Poecilostomatoida: Rhynchomolgidae) había sido citada en Europa viviendo en asociación con gorgonias. Doridicola botulosus (Stock and Kleeton, 1963) vive sobre la gorgonia mediterránea Eunicella singularis (Esper, 1791). Durante una serie de muestreos a lo largo de la costa ibérica mediterránea, numerosos ejemplares de D. botulosus fueron encontrados en su huésped original. Además, una especie no descrita de Doridicola fue descubierta viviendo en asociación con Paramuricea clavata (Risso, 1826), una gorgonia mediterránea cuyas poblaciones pueden solapar con aquellas de E. singularis. Aunque la nueva especie es próxima a D. botulosus, ésta difiere en los apéndices bucales. Es sugerido un origen común para ambas especies de copépodos. Este es un buen ejemplo de formación de especies gemelas producidas por la colonización de dos huéspedes cuyos hábitats solapan.

Palabras clave: Mediterráneo, octocorales, Copepoda, simbiosis, especiación, especie nueva.

\section{INTRODUCTION}

Copepods show diversity in habitat and life styles, and this is particularly seen in their diversification as symbionts or parasites of other animals (Gotto, 1979; Raibaut, 1985; Svavarsson, 1990). Those associated with invertebrates show every step, from a free-living, non-transformed creature, via

*Received March 21, 2003. Accepted September 10, 2003. moderately adapted forms, to an unrecognisably transformed, truly parasitic animal. As a result, these copepods display a great morphological variation which can be attributed to the grade of parasitism and to its host specificity as well as to the influence of a geographical isolation.

The phenomenon of host specificity is the extent to which a parasite is restricted in the range of hosts that it utilises. Levels of host specificity can range through a continuum from high, with the parasitic species 
occurring on only a single host species, to low, with the parasite occurring on a wide range of phylogenetically unrelated host species (Boxshall, 1998).

The lichomolgoid complex (Copepoda: Poecilostomatoida) includes free living copepods and fairly unspecialised symbiotic copepods. Its recent revision divided this complex into ten families, the majority of them established on the basis of morphological similarity, using exclusively or predominantly a single host category (Humes and Boxshall, 1996). Thus, the large family Rhynchomolgidae Humes and Stock, which comprises 41 genera and more than 230 species, is mainly associated with cnidarians. However, Doridicola Leydig and Critomolgus are the only genera within the family that use a wide range of hosts. The remaining genera live in association with one particular host group within the Cnidaria.

The hypothetical historical (evolutionary) relationships between the species of Doridicola and its three host phyla: cnidarians (Hydrozoa and Anthozoa), molluscs (Bivalvia, Gastropoda and Cephalopoda) and echinoderms (Asteroida and Ophiuroidea) have recently been studied (Ho and Kim, 2001). Although the cladistic analysis was based strictly on morphological information, the cladogram obtained revealed certain degrees of relationship between the symbionts and their hosts. Thus, the study indicates that the ancestral stock of the modern species of Doridicola diverged into two lineages early in its evolution, with one exploring life on octocorallians (alcyonaceans and gorgonaceans) and the other mainly on alcyonaceans and gastropod mollusks. Following Ho and Kim (2001), the only European Doridicola species associated with a gorgonian, Doridicola botulosus (Stock and Kleeton, 1963), would be a descendant of the second lineage. Doridicola botulosus was described living on the Mediterranean gorgonian, Eunicella singularis (Esper, 1791), and has not been reported since then. In the present study, in addition to reporting new records of $D$. botulosus from the Mediterranean and describing a new European species of Doridico$l a$, a hypothesis dealing with the origin of these two species associated with two different Mediterranean gorgonians is proposed and discussed.

\section{MATERIAL AND METHODS}

Fragments from large colonies of the gorgonian Paramuricea clavata were collected from three different infralittoral zones on the Iberian Mediterranean coast: Gibraltar Harbour (Algeciras Bay, Southern Iberian Peninsula); Hormigas Islands (Cabo de Palos, southeastern Iberian Peninsula) and Medes Islands (L'Estartit, northeastern Iberian Peninsula). Fragments from Eunicella singularis were also collected in two of these areas (Fig. 1).

The samples were immediately fixed by adding progressively Formalin (4\% in sea water) to make a concentration of approximately $2 \%$. Later, the fixative-sea water was passed through a $100 \mu \mathrm{m}$ net. The copepods were then recovered from the sediment retained and later preserved in $70 \%$ ethanol. For microscopical study, whole specimens were stained with Chlorazole black E (Sigmå C-1144) and dissected under a stereomicroscope. Permanent mounts were made in Lactophenol and sealed with Entellan (Merck® 1.07961.0100). All figures were drawn

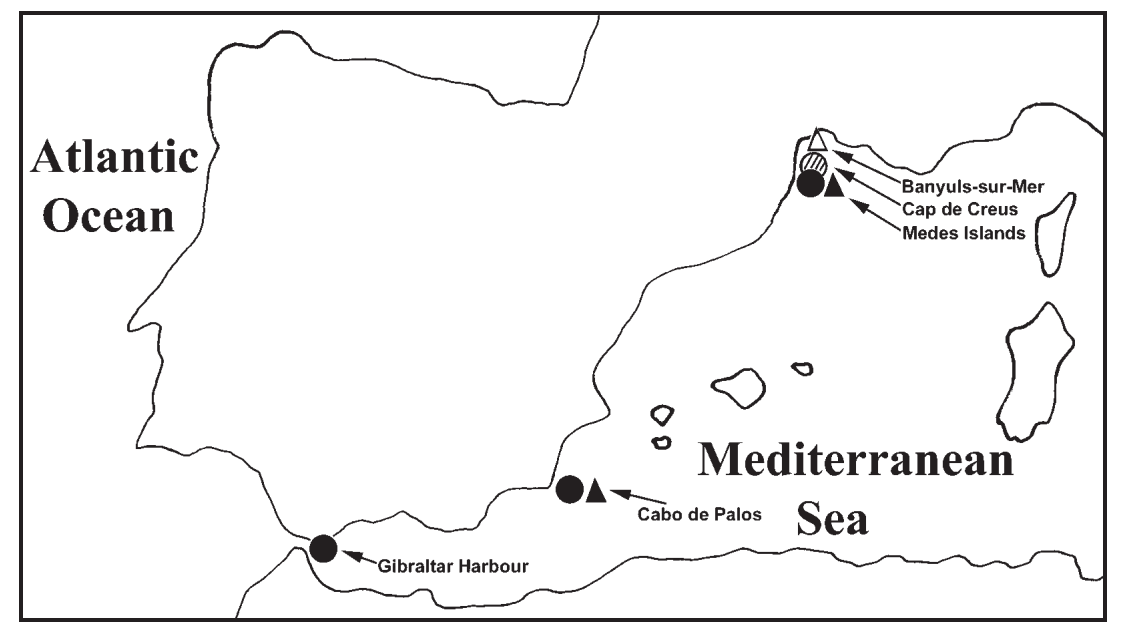

FIG. 1. - Geographical known distribution of Doridicola botulosus (Stock and Kleeton, 1963) and D. comai sp. nov. Open triangle: type locality of $D$. botulosus. Solid triangles: new records of D. botulosus. Striped circle: material recorded as D. botulosus by Stock and Kleeton (1963: 247) corresponding to D. comai sp. nov. (see Discussion). Solid circle: D. comai sp. nov., Gibraltar Harbour is the type locality. 
with the aid of a camera lucida on a Leica DMLB differential interference microscope.

For scanning electron microscopy (SEM) studies, selected specimens were post-fixed in $2.5 \%$ glutaraldehyde in $0.2 \mathrm{M}$ cacodylate buffer at $\mathrm{pH} 7.3$ and in $1 \% \mathrm{OsO}_{4}$ in the same buffer and subsequently critical point dried, mounted on stubs, coated with goldpalladium and observed with a PHILIPS XL30.

For purposes of comparison, the following material was also examined:

- Lichomolgus botulosus Stock and Kleeton, 1963. 1 female Holotype, 1 male Allotype, 12 females, 3 males and 20 copepodite paratypes associated with Eunicella stricta (Bert.) in Banyuls (France), 10 m, August 1961 (Co-100.747 ZMA).

Remarks: In the labels of this type material the indication of the host [Eunicella verrucosa (Pall.)] differs from that given by the authors in the publication [Eunicella stricta (Bert.)]. Currently, E. stricta is a well known junior synonym of Eunicella singularis (Esper, 1791) (see Carpine and Grasshoff, 1975, Weinberg, 1975 for additional nomenclatural details). The host identity was already commented in the original description (Stock and Kleeton, 1963: 247, footnote), although this mistake was not resolved as a new label to be included with the type specimens.

- Lichomolgus botulosus Stock and Kleeton, 1963. 1 female at Cap de Creus (Spain) associated with Paramuricea chamaeleon (von Koch), 20-23 m. depth, August 1961 (Co-100.748 ZMA).

Remarks: According to Carpine and Grasshoff (1975), all Mediterranean references to $P$. chamaeleon should be considered as Paramuricea clavata (Risso, 1826). The revision of this material revealed that it must be placed in the new species of Doridicola described in this paper as D. comai sp. nov. (see below).

\section{RESULTS}

Order Poecilostomatoida Thorell, 1859

Family RhynCHOMOLGIDAE Humes and Stock, 1972

\section{Doridicola botulosus (Stock and Kleeton, 1963)} (Fig. 2)

Lichomolgus botulosus Stock and Kleeton, 1963: 247 (in part, only the material associated with Eunicella stricta).

Material examined: 5 females, 8 males and 10 copepodites at Medes Islands, 25-30 m. depth, March, 2001. 3 females and 3 males at Cabo de Palos, 25 m. depth, June, 2002 (Fig. 1). All copepods were found associated with Eunicella singularis.
Remarks: This species was described in detail as Lichomolgus botulosus by Stock and Kleeton (1963). Ten years later, it was assigned by Humes and Stock (1973) to the new genus described by these authors (1972), Metaxymolgus, which was later synonymised with the genus Doridicola (Humes and Stock, 1983).

The slender antenna, with two subequal terminal claws nearly as long as the fourth segment, the long spines on lash of the second maxilla, forming a crest (Fig. 2c) and the large (outer) seta on the middle segment of the female maxilliped (nearly 3 times longer than the segment and 7 times longer than the medial seta) (Fig. 2d) are some diagnostic characteristics of D. botulosus.

The specimens of D. botulosus studied in this work differ slightly from those drawn by Stock and Kleeton in the armature of the antenna and the maxillule as well as in the structure of the mandible. Those specimens found in Banyuls have a maxillule armed with 3 setae whilst the newly collected specimens have 4 unequal setae. However, as this seta is small and difficult to see, it is likely that Stock and Kleeton overlooked it. With respect to the second antenna, our specimens have a slender claw-like seta on the third segment (Fig. 2f) which is not clearly shown in the original drawings. There is also some variation in the mandible since the newly collected specimens show a more complex structure on the inner margin of this appendage (Fig. 2a). As D. botulosus is a well described species, we have only drawn those parts which are clearly different from the new Doridico$l a$ and those parts which have some kind of variation with respect to the original description.

Doridicola comai, sp. nov.

(Figs. 3-8)

Lichomolgus botulosus Stock and Kleeton, 1963: 247 (in part, only the material associated with Paramuricea chamaeleon).

Material examined: 54 females, 33 males and several copepodites at Gibraltar Harbour, $20 \mathrm{~m}$. depth, June 1998; 1 female and 3 males at Medes Islands, 25-30 m. depth, March, 2001; 1 female and 3 males at Cabo de Palos, 30 m. depth, June, 2002 (Fig. 1). All copepods were associated with Paramuricea clavata. The holotype female and allotype male have been deposited in the Museo Nacional de Ciencias Naturales in Madrid, Spain with the registration numbers MNCN (20.04/5885) and MNCN (20.04/5886) respectively.

Female: Body (Fig. 3a) 91-1014 $\mu \mathrm{m}$ long (excluding setae on caudal rami) and 464-510 $\mu \mathrm{m}$ wide (greatest width of cephalothorax) based on six females in lactic acid. First pediger separated from 


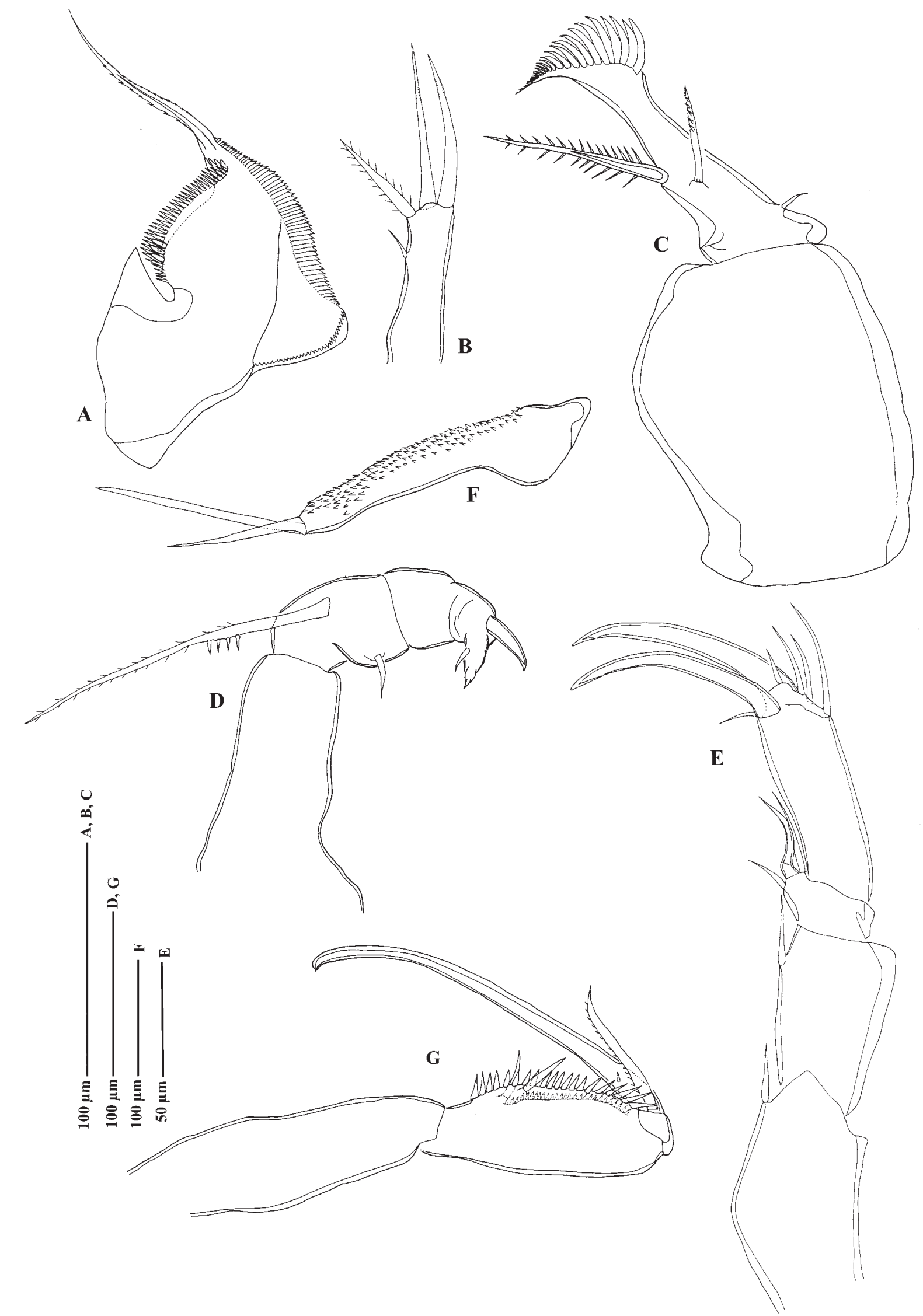

FIG. 2. - Doridicola botulosus. Female. A, mandible; B, maxillule; C, Maxilla; D, maxilliped; E, free segment of leg 5. Male. F, maxilliped. 


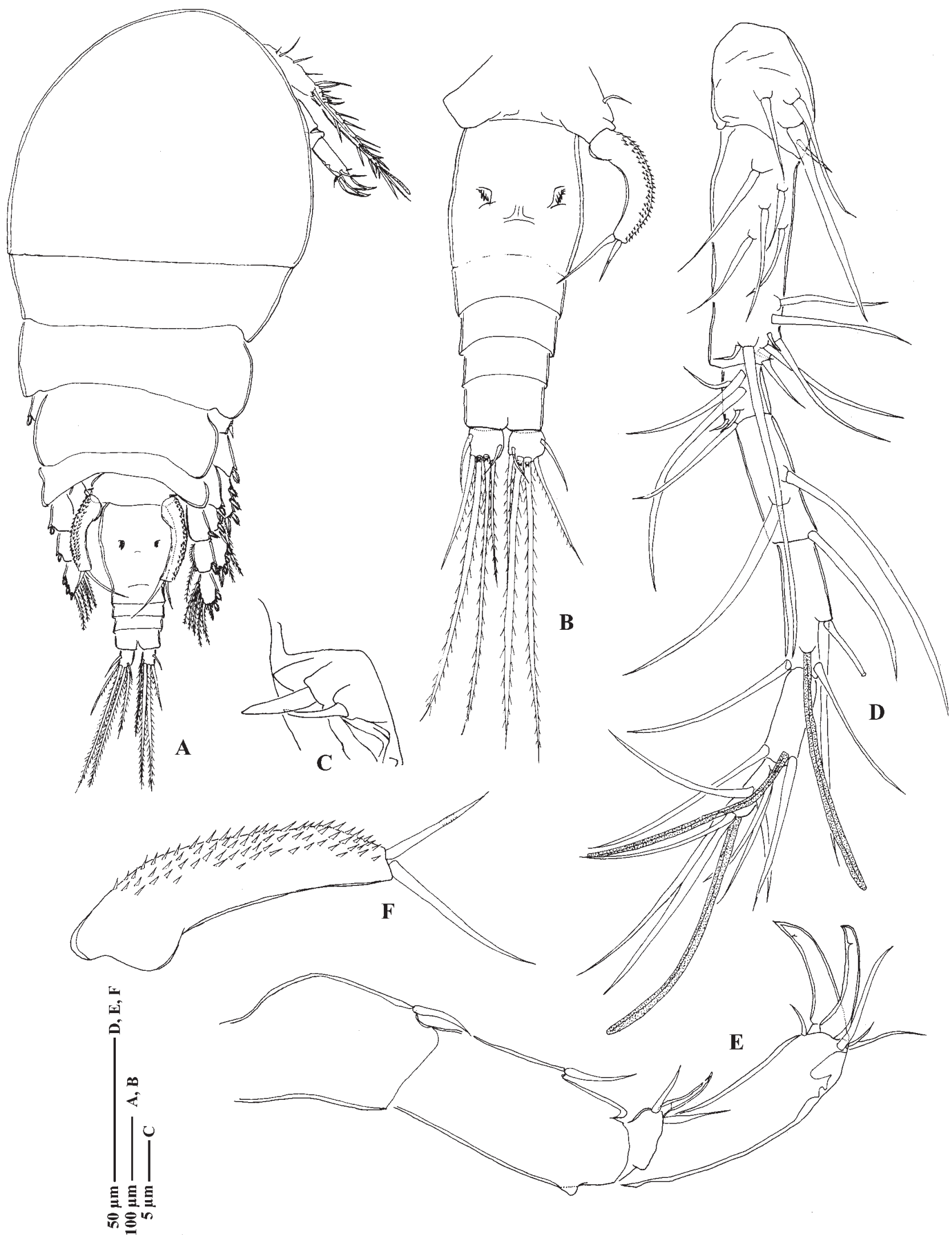

FIG. 3. - Doridicola comai, sp. nov. Female. A, habitus, dorsal; B, urosome, dorsal; C, genital area; D, antennule; E, antenna; F, free segment of leg 5 . 

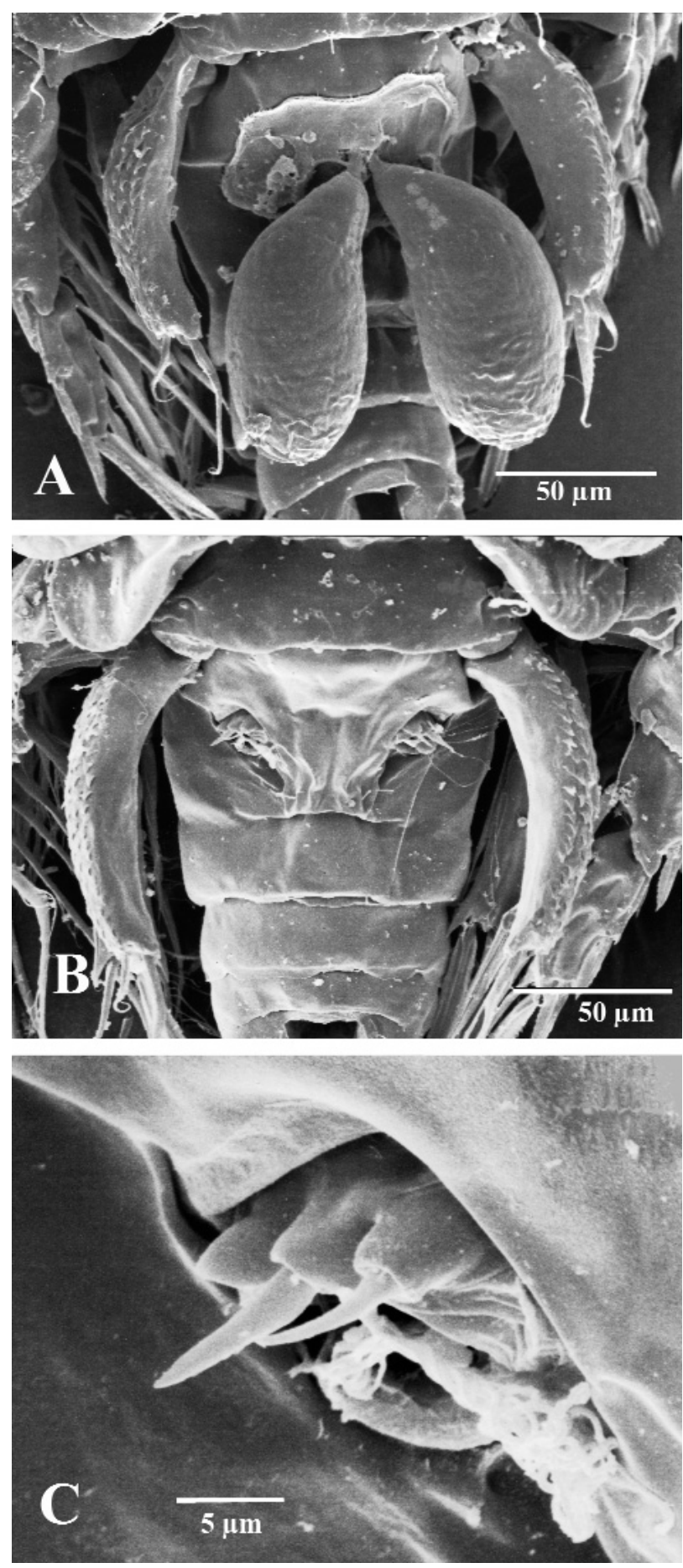

FIG. 4. - Doridicola comai, sp. nov. Female. A, spermatophores, attached to female, dorsal; B, urosome, dorsal; C, genital area.

cephalosome by distinct dorsal furrow and broadly protruded at posterolateral corners. Genital-double somite (Figs. 3b, 4b) 1.3 times longer than wide, 271.4 x $207 \mu \mathrm{m}$, with prominent anterodorsal bulge expanding laterally to egg sac attachment area (Figs $3 \mathrm{~b}, \mathrm{c} ; 4 \mathrm{~b}, \mathrm{c})$ and over-hanging narrow posterior part of somite proper. Three free abdominal somites (Fig. 3b, 4a, b) 150 x 64.3, 128.6 x 57, and 121.4 x $86 \mu \mathrm{m}$ respectively. Caudal ramus (Fig. 2a,b) as long as wide, measuring 57 x $50 \mu \mathrm{m}$ and bearing the usual six setae in terminal area.

Rostrum broadly rounded posteroventrally. Antennule (Fig. 3d) 7-segmented, with armature formula: 4, 13, 6, 3, 4+1 aesthete, $2+1$ aesthete, and 7+1 aesthete. Antenna (Fig. 3f) 4-segmented; with formula of armature: 1, 1, 2+1 claw, and $4+$ 2 subequal claws. Labrum with two large, divergent posteroventral lobes. Mandible (Fig. 5a) with shallow but wide proximal notch followed by row of long slender spinules decreasing in length on inner margin; convex margin with outer scale bearing row of spinules; terminal lash not very long, setulose on both sides. Maxillule (Fig. 5b) armed with 4 unequal setae, 3 terminal and 1 sub-terminal. Maxilla (Fig. 5c) 2-segmented; proximal segment (syncoxa) inflated and unarmed; distal segment (basis) ornamented with the three typical setae. A tiny outer setula (seta III) at base, plumose seta (seta II) on anterior surface, and seta armed with spinules (seta I) as long as seta II proximal to the base of the main lash. Terminal lash armed along one side with large spinules. Maxilliped (Fig. 5d) 3-segmented; proximal segment (syncoxa) largest but unarmed; middle segment (basis) carrying two very unequal setae (3:1) with longer (outer) seta bearing spinules on one side; distal segment (endopod) terminating in spiniform process and carrying another spiniform process and a simple seta at base.

Legs 1-4 (Figs. 6a-d) biramous, with 3-segmented rami except 2-segmented endopod of leg 4 . Formula of spines (in Roman numerals) and setae (in Arabic numerals) as follows:

\section{Coxa Basis Exopod Endopod}

Leg $1 \quad 0-1 \quad 1-0 \quad$ I-0; I-1; III,I,4 0-1; 0-1; I,5

Leg 2 0-1 1-0 I-0; I-1; III,I,5 0-1; 0-2; I,II,3

Leg $3 \quad 0-1 \quad 1-0 \quad$ I-0; I-1; III,I,5 0-1; 0-2; I,II,2

Leg $4 \quad 0-1 \quad 1-0 \quad$ I-0; I-1; II,I,5 0-1; II

Leg 5 (Fig. 3b, e; 4a, b) with elongate free segment measuring $113 \mu \mathrm{m}$ long; greatest width at proximal inner expansion $34 \mu \mathrm{m}$. Two terminal setae, simple and unequal in length, the inner one nearly 1.5 times longer than the outer one. Leg 6 (Figs. 3c, 4c) located on posterodorsal surface of genital double-somite, composed of a conical process and two small setae. Spermatophore $98 \mathrm{x}$ $47.4 \mu \mathrm{m}$ (Fig. 4a). 


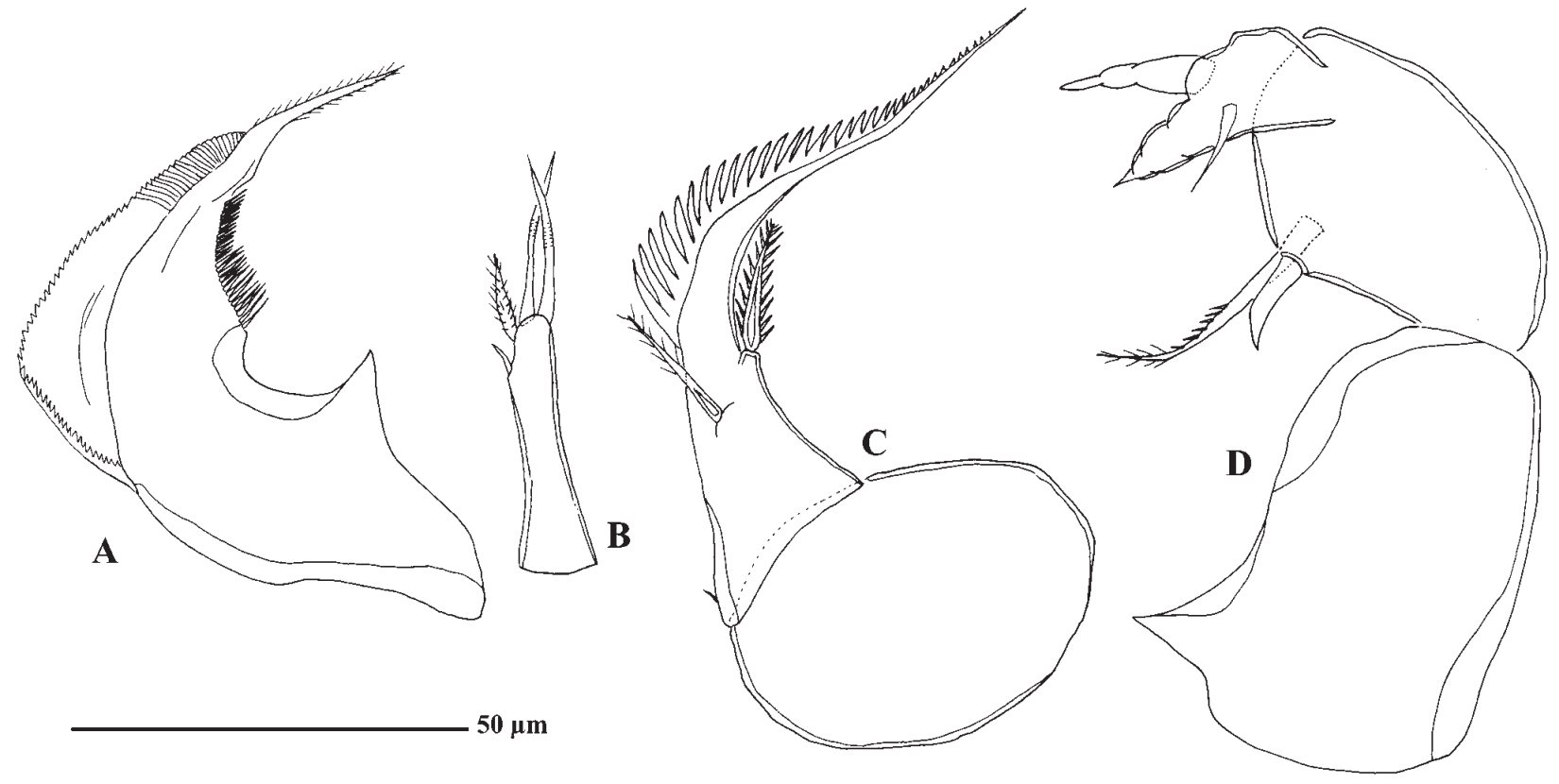

FIG. 5. - Doridicola comai, sp. nov. Female. A, mandible; B, maxillule; C, maxilla; D, maxilliped.

Male: Body (Fig. 7a) $668 \mu \mathrm{m}$ long, with 6-segmented urosome. Genital somite (Fig. 7b, 8a) slightly longer than wide. Caudal ramus subquadrate, 50 x $41 \mu \mathrm{m}$. Rostrum, antennule, labrum (Fig. 8b), mandible, maxillule and maxilla resembling those of female. Antenna (Fig. 7d) slightly different from female in having spinules on the surface of the first and second segments. Maxilliped (Fig. 7e, 8c) 4segmented; first segment (syncoxa) large but unarmed; second segment (basis) armed with two rows of spinules and two inner setae; third segment (endopod) smallest and unarmed; terminal claw long, with terminal lamellae and one long distally barbed seta at the basal region. Third endopod segment of leg 1 (Fig. 7f) armed with two spines and four setae, and second endopodal segment of leg 4 (Fig. $7 \mathrm{~g}$ ) with two spines. Free segment of leg 5 (Fig. 7c, 8a) small, 36.5 x $6 \mu \mathrm{m}$ (6:1), tipped with two unequal, simple setae. Leg 6 (Fig. 7b) composed of two ventral setae, the inner one with setules, located at posterolateral corner of genital somite.

Etymology: The specific name comai is after our friend and colleague Rafel Coma, who enthusiastically encouraged us to sample the gorgonian Paramuricea clavata in the Strait of Gibraltar.

Remarks: Among the 45 species currently recognised in the genus Doridicola, only twelve species have the distomedial seta of the third segment of the antenna transformed into a claw or a spiniform ele- ment. Such transformations are considered an apomorphic state (Ho and Kim, 2001). Species with such transformations are: D. aculeatus (Humes and Ho, 1968), D. agilis Leydig, 1853, D. botulosus (Stock and Kleeton, 1973, this paper), D. chlamydis (Humes and Stock, 1973), D. hetaericus (Humes and Stock, 1968), D. inflatiseta (Humes and Stock, 1973), D. longicauda (Claus, 1860); D. securiger (Humes, 1964), D. sensilis (Humes, 1964), D. sepiae (Izawa, 1976), D. similis (Ho and Kim, 2001) and D. singularipes (Humes and Ho, 1968).

Among these species, only D. aculeatus, D. botulosus, D. hetaericus, D. sensilis and D. singularipes have the two terminal claws of the antenna subequal in size like D. comai. Nevertheless, four of these five species can be easily separated from $D$. comai by the combination of the following three features: (1) maxilla with a tiny seta III, a barbuled seta I nearly as long as the setulose seta II; (2) maxilliped with an outer seta barbuled on its outer surface and setulose on both sides of its distal part and nearly or more than three times longer than the medial seta; (3) leg 5 with basal swelling, bearing spinules along its outer surface and carrying two unequal terminal setae. These distinct characteristics set the new species apart from all known congeners but morphologically close to other European species: D. botulosus, which lives on a Mediterranean gorgonian species, Eunicella singularis, that usually inhabits similar habitats to Paramuricea clavata. However, both species can be clearly distinguished by the 


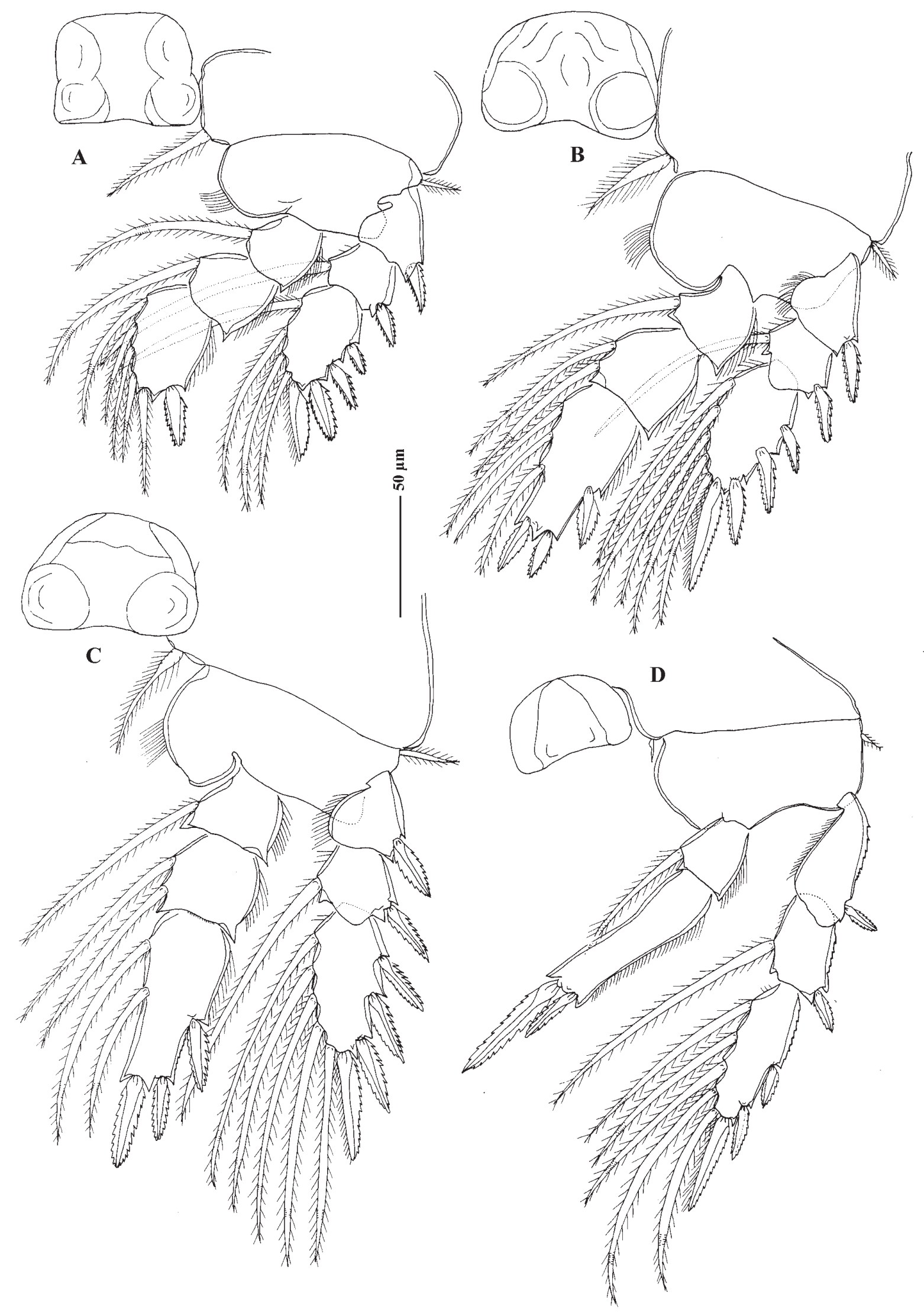

FIG. 6. - Doridicola comai, sp. nov. Female. A, leg 1; B, leg 2; C, leg 3; D, leg 4. 


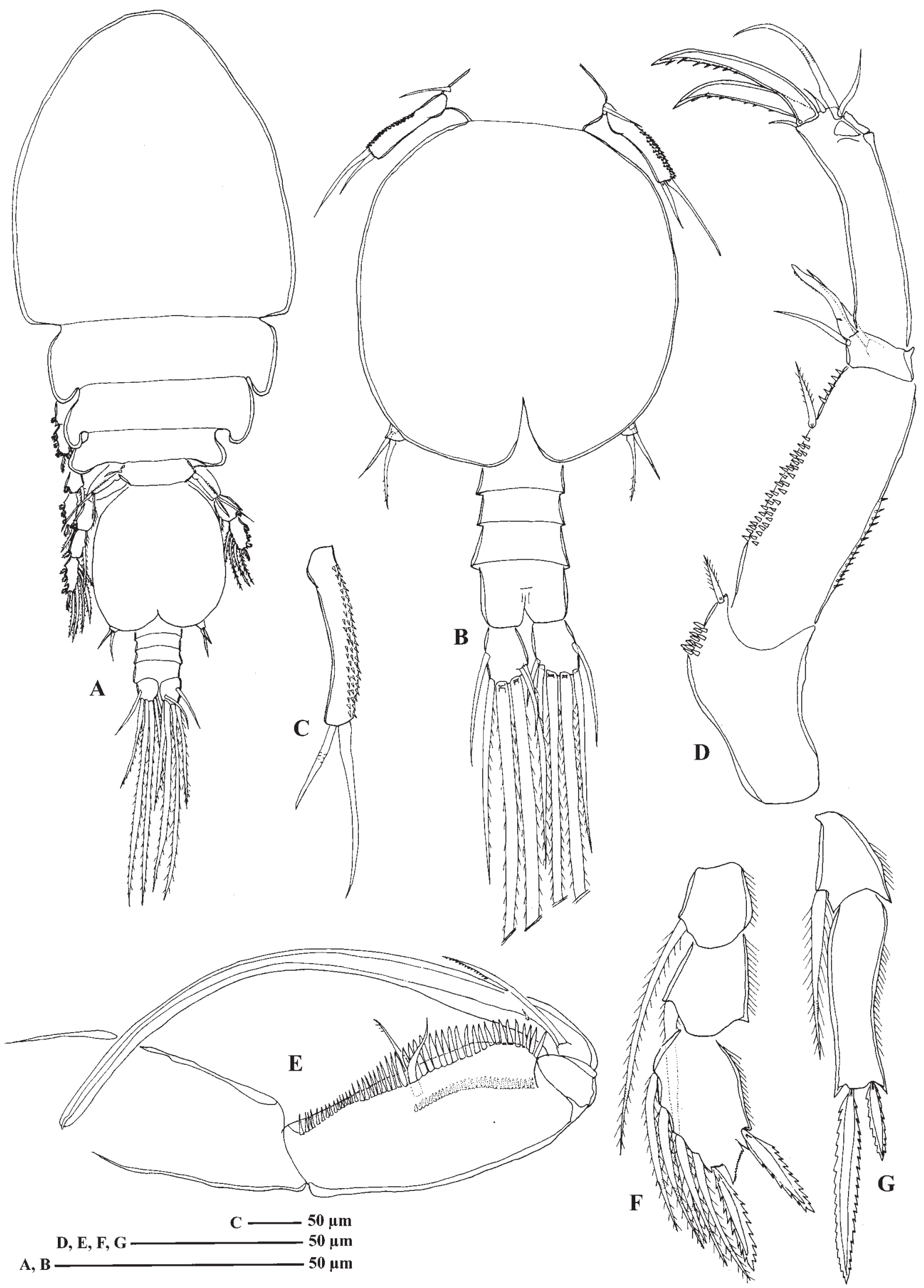

FIG. 7. - Doridicola comai, sp. nov. Male. A, habitus, dorsal; B, urosome, dorsal; C, free segment of leg 5; D, antenna; E, maxilliped; F, endopod of leg 1; G. endopod of leg 4. 

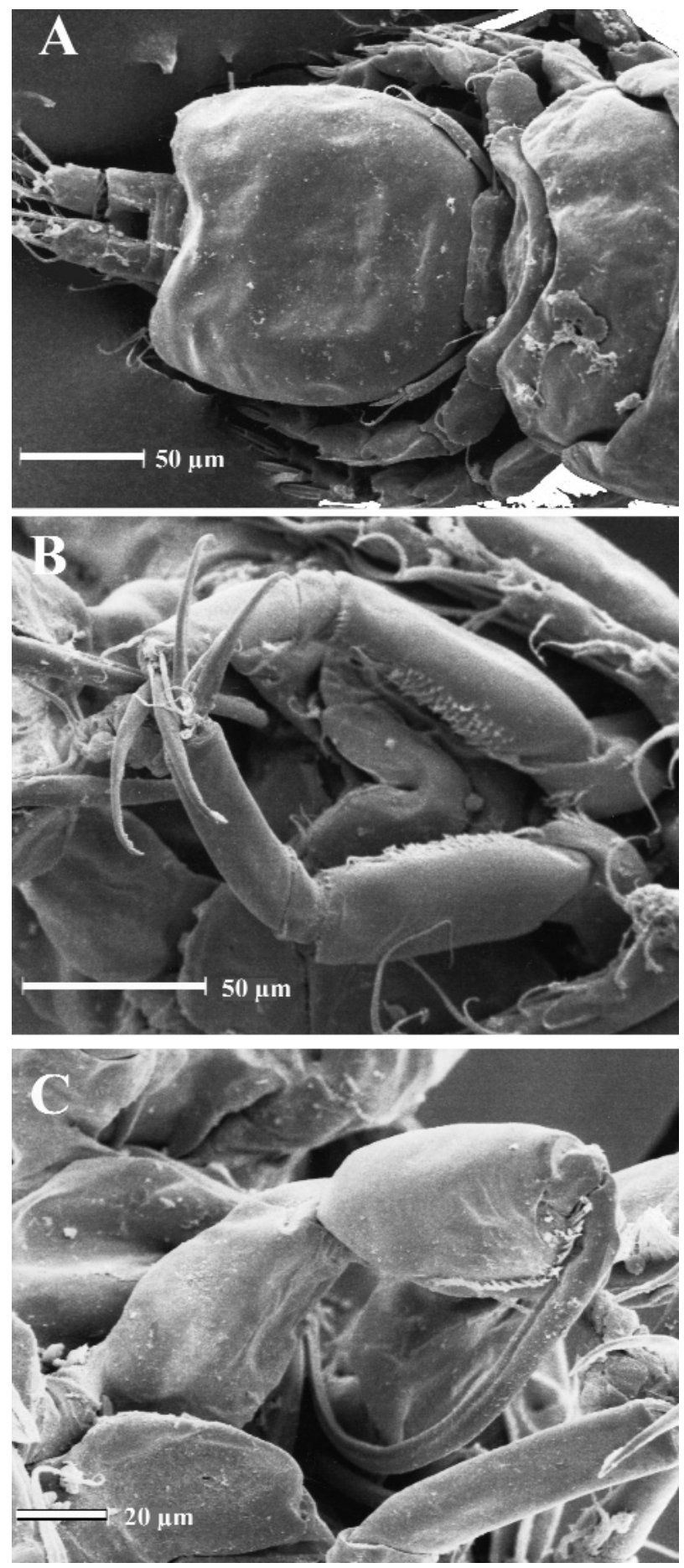

FIG. 8. - Doridicola comai, sp. nov. Male. A, urosome, dorsal; B, antenna; $\mathrm{C}$, maxilliped.

shape and armature of the mandible (Figs. 2a, 5a), the shape and the length of the lash of the maxilla (Figs 2c, 5c), the length of the two unequal setae on the middle segment of the maxilliped (Figs. 2d, 5d) and the distomedial seta of the third segment of the antenna which is transformed into a claw in $D$. comai (Fig. 3e) and into a claw-like seta in D. botu- losus (Fig. 2f). As mentioned above, the specimen reported by Stock and Kleeton (1963) associated with Paramurica clavata in Cap Creus (ZMA Co. 100.747) must be assigned to Doridicola comai.

\section{DISCUSSION}

It is widely accepted that the many complex interactions in host-parasite co-evolution do not allow taxa to be linked in monophyletic clades solely on the basis of their shared host affiliation (Huys, 2001). However, certain aspects of copepod biology, such as host switching, especially in copepod symbionts where it is a common phenomenon, might throw some light on the group's past history (Gotto, 1998). Some examples are the cyclopoid family Notodelphyidae, commonly associated with ascidians but with some species inhabiting octocorals (Stock and Humes, 1970) resembling their ascidiandwelling relatives, and the family Mantridae, whose species are known to occur in bivalves, and present strong evidence of having arisen from ascidicolous ancestors (Huys, 1990; Ho, 1994).

Although host-switching can sometimes be explained in simple opportunistic terms, the selective advantages of switching hosts are obvious since new hosts mean new horizons of evolutionary opportunity and also provide more chance to survive (Gotto, 1998). Nevertheless, the mechanics of the process has not yet been determined. Ho (1994) believes that competition can mould host specificity in copepods, so that the ancestral cyclopoid in sponges was lost in competition for food and shelter with the siphonostomes, and in bivalves with the poecilostomatoids. Another example of competition, in this case at species level, occurs between the caligids Lepeophtheirus thompsoni and $L$. europaensis, two parasitic copepods naturally isolated on their hosts, turbot (Psetta maxima L.) and brill (Scophthalmus rhombus L.) respectively. They are able to meet, mate and hybridise on turbot experimentally but they are prevented from doing so by a strong host preference when given a choice (Dawson et al., 2000). This pattern is a result of a greater sensitivity to competition for the generalist species $L$. europaensis than for the specialist $L$. thompsoni.

Later on, Gotto (1998) postulated an altered receptor as the mechanism which triggers a new association. According to this hypothesis, the biochemical recognition between copepod and host might be of prime importance, so if the copepod's 
sensory receptor undergoes some sort of change and does not respond to the cue of the usual host, a switch to a new host would probably occur. However, this receptor would presumably be capable of picking up a different signal on which the searching larva might hopefully home. On arrival at the source, and should conditions prove suitable for invasion and residence, a new alliance may then be born. There is no evidence to sustain this hypothesis, but there are some genera of symbiotic copepods, which live on different hosts, or even different parts of the same hosts, that are rich in sympatric species (Lonning and Vader, 1984). If a population exploits several different habitats, an adaptive polymorphism can be maintained (Levene, 1953). A reduced migration between these different habitats can greatly enhance the stability of this polymorphism (Moran, 1959, Eyland, 1971) and may even lead the population into a process of genetic isolation (Balkau and Feldman, 1973). Lepeophtheirus europaensis can also be taken as an example of adaptive polymorphism since this ectoparasite can live on two different hosts in the Gulf of Lions (Mediterranean, France): the brill (Scophthalmus rhombus), a marine scophthalmid, and the flounder (Platichthys flesus), a pleuronectid inhabiting lagoons (brackish water) (Zeddam et al., 1988). L. europaensis from brills may colonise flounders during their reproductive migrations, but these parasites will encounter unfavourable conditions when the flounders return to the lagoons since they are unable to live at salinities encountered in lagoons (De Meeüs et al., 1990). These differences in adaptation lead to a very low rate of exchange between the two populations, a phenomenon encouraging conditions for protected adaptive polymorphism. Thus, the taxon L. europaensis can represent the beginning of a sympatric speciation currently occurring in the Gulf of Lions (De Meeüs et al., 1992). Another example of speciation are the twin species Astericola clausi and A. asterinae, lichomolgid symbionts of the European asteroids Marthasterias glacialis (O.F. Müller) and Asterina gibbosa (Pennant), which are likely to be derived from a common ancestor (Bocquet et al., 1970; Conradi et al., 1993).

Allopatric speciation through postzygotic genetic incompatibilities has been the dominant view of speciation for the past six decades (Turelli et al., 2001). In this scenario, sympatric speciation has been extremely controversial. Sympatric speciation was defended by a stalwart group of empiricists but thought by many to be implausible and of limited applicability. Some authors understand sympatric speciation as a short-scale allopatric speciation (e.g. switching host, different microhabitats inside the same host, displacement of the reproductive period). Recently, Via (2001) postulates that sympatric speciation can occur under a variety of conditions (see also Turelli et al., 2001). However, the underlying idea is that it might be time for a re-evaluation of the geographical classification of speciation modes in favour of one based primarily on evolutionary mechanisms.

The two Doridicola species associated with Mediterranean gorgonians, D. botulosus and $D$. comai, are so morphologically similar that they may be regarded as sister species and would represent a good example of speciation producing sibling species by the colonisation of two related hosts. The geographical distribution of $E$. singularis resembles that of Paramuricea clavata, and they can sometimes be found living together. However, from the ecological point of view, E. singularis is a photophilic gorgonian with a depth range up to 50 meters (Weinberg, 1975). On the other hand, $P$. clavata is a sciaphilic gorgonian with a deeper distribution, usually being abundant at 50-60 metres in the Mediterranean (Carpine and Grasshoff, 1975). There are some places of the Mediterranean coast where the deeper range of the Eunicella overlaps with the superficial range of Paramuricea, and therefore both species cohabit.

According to cladogenesis (see De Queiroz, 1998), there are two possibilities to explain the origin of these two Doridicola species: 1) the budding model: one of the Doridicola species is the origin of the other, and both species (original and new) coexist in time, naturally isolated on their respective hosts; and 2) the bifurcating model: an ancestral Doridicola species living in the overlapping deep range of these two Mediterranean gorgonians gave rise to two subpopulations living on these related hosts. The original species did not persist in time, but the two subpopulations evolved as different species including their own apomorphies.

After Carton's studies, the first possibility (budding model) could explain the case of Astericola clausi and Astericola asterinae (see Bocquet et al., 1970; Carton, 1964). However, both Doridicola species, D. botulosus and D. comai, show apomorphic stages in different appendages $(D$. botulosus has a more derived set of oral appendages, while $D$. comai has a more transformed second antenna including a claw on the third segment instead of the 
claw-like seta present in D. botulosus). Thus, the second possibility (the bifurcating model) could be the most plausible in this case.

\section{ACKNOWLEDGEMENTS}

The authors are very grateful to Javier Ari Rojas for his invaluable help during sampling. We are deeply obliged to Dr. J.-S. Ho for generous information and comments during the elaboration of this paper and to Dirk Platvoet, curator of the Zoological Museum of Amsterdam, for loaning the material of this museum. This work was supported financially by the Spanish project "Gorgonias Mediterráneas Ibéricas" (REN2000-0633-C03-03) under the auspices of the Ministerio de Ciencia y Tecnología.

\section{REFERENCES}

Balkau, B.J. and M.W. Feldman. - 1973. Selection from migration modification. Genetics, 74: 171-174.

Bocquet, C., Y. Carton and M.M. Sroehlich. - 1970. Étude de deux epèces jumelles de copépodes parasites: Stellicola clausi (Rosoll) et Stellicola asterinae (Bocquet). Arch. Zool. Exp. Gen., 11(4): 497-520.

Boxshall, G.A. - 1998. Host specificity in copepod parasites of deep-sea fishes. J. Mar. Syst., 15: 215-223.

Carpine, C. and M. Grasshoff. - 1975. Les Gorgonaires de la Méditerranée. Bull. Inst. oceanogr. Monaco, 71(1430): 1-140.

Carton, Y. - 1964. Spécifité relative a l'intérieur de l'espèce Stellicola clausi (Rosoll), Copépode Cyclopoïde parasite des deux stellérides Marthasterias glacialis (L.) et Asterina gibbosa (Penn.). Arch. Zool. Exp. Gén., 103(1): 13-19.

Conradi, M., P.J. López-González, J.I. González-Gordillo and J.C. García-Gómez. - 1993. Copepods associated with marine invertebrates in the Iberian Peninsula. I.: The genus Astericola Rosoll, 1889 (Copepoda: Lichomolgidae). Arq. Mus. Bocage, 2(20): 363-377.

Dawson, L.H., F. Renaud, J.F. Guégan and T. De Meeüs. - 2000. Experimental evidence of asymmetrical competition between two species of parasitic copepods. Proc. R. Soc. London, 267(1456): 1973-1978.

De Meeüs, T., R. Marin and F. Renaud. - 1992. Genetic heterogeneity within populations of Lepeophtheirus europaensis (Copepoda: Caligidae) parasitic on two host species. Int. J. Parasitol., 22(8): 1179-1181.

De Meeüs, T., F. Renaud and C. Gabrion. - 1990. A model for studying isolation mechanisms in parasite populations: the genus Lepeophtheirus (Copepoda: Caligidae). J. Exp. Zool., 254: $207-214$

Eyland, E.A. - 1971. Moran's island migration model. Genetics, 69: 399-403.

Gotto, R.V. - 1979. The association of copepods with marine invertebrates. Adv. mar Biol., 16: 1-109.
Gotto, R.V. - 1998. Reflections on host-switching as a factor in the evolution of associated copepods. J. Mar. Sci., 15: 225-227.

Ho, J-S. - 1994. Origin and evolution of the parasitic cyclopoid copepods. Int. J. Parasitol., 24: 1293-1300.

Ho, J-S. and C. Kim. - 2001. New species of Doridicola (Copepoda, Rhynchomolgidae) from Thailand, with a cladistic analysis of the genus. J. Crust. Biol., 21(1): 78-89.

Humes, A.G. and G.A. Boxshall. - 1996. A revision of the lichomolgoid complex (Copepoda: Poecilostomatoida), with the recognition of six new families. J. Nat. Hist., Lond. 30: 175-227.

Humes, A.G. and J.H. Stock. - 1972. Preliminary notes on a revision of the Lichomolgidae, cyclopoid copepods mainly associated with marine invertebrates. Bull. Zool. Mus., Univ. Amsterdam 2(12): 121-123.

Humes, A.G. and J.H. Stock. - 1973. A revision of the family Lichomolgidae Kossmann, 1877, cyclopoid copepods mainly associated with marine invertebrates. Smith. Contr. Zool. 127: $1-308$.

Humes, A.G. and J.H. Stock. - 1983. Redefinition of the genus Doridicola Leyding, 1853, synonymy of Metaxymolgus Humes and Stock, 1972, and establishment of a new genus, Critomolgus (Copepoda, Poecilostomatoida, Lichomolgidae). Bull. Zool. Mus., Univ. Amsterdam 9(10): 93-96.

Huys, R. - 1990. Allocation of the Mantridae (Leigh-Shape) to the Cyclopoida (Crustacea: Copepoda) with notes on Nearchinotodelphys Ummerkutty. Bijdr. Dierk., 60: 283-291.

Huys, R. - 2001. Splanchnotrophid systematics: a case of polyphyly and taxonomic myopia. J. Crust. Biol., 21(1): 106-156.

Levene, H. - 1953. Genetic equilibrium when more than one ecological niche is available. Am. Natur., 87: 331-333.

Lonning, S. and W. Vader. - 1984. Sibling species of Doridicola (Copepoda:Lichomolgidae) from California sea anemones: Biology and host specificity. J. Exp. Mar. Biol. Ecol., 77: 99-135.

Moran, P.A.P. - 1959. The theory of some population genetics effects of population subdivision. Austr. J. Biol. Sci., 12: 109-116.

Queiroz, K. de. - 1998. The general lineage Concept of species, species criteria, on the process of speciation: A conceptual unification and terminological recommendations. In: D.J. Howard and S.H. Berlocher (eds), Endless Forms: species and speciation, pp. 57-75. Oxford Univ. Press, New York.

Raibaut, A. - 1985. Les cycles évolutifs des copépodes parasites et les modaliés de l'infestation. Ann. Biol., 24(3): 233-274.

Stock, J.H. and A.G. Humes. - 1970. On four new notodelphyid copepods, associated with an octocoral, Parerythropodium fulvum (Forskal), in Madagascar. Zool. Anz., 184: 194-212.

Stock, J.H. and G. Kleeton. - 1963. Copépodes associés aux invertébrés des côtes du Roussillon. 2. - Lichomolgidae. Ectoassociés d'octocoralliaires. Vie Milieu, 14(2): 245-261.

Svavarsson, J. - 1990. Life cycle and population dynamics of the symbiotic copepod Lichomolgus canui Sars associated with the ascidian Halocynthia pyriformis (Rathke). J. Exp. Mar. Biol. Ecol., 142: 1-12.

Turelli, M., N.H. Barton and J.A. Coyne. - 2001. Theory and speciation. Trends Ecol. Evol., 16(7): 330-342.

Via, S. - 2001. Sympatric speciation in animals: the ugly duckling grows up. Trends Ecol. Evol., 16(7): 381-389.

Weinberg, S. - 1975. Écologie des octocoralliaires communs du substrat dur dans la region de Banyuls-Sur-Mer. Bijd. Dierk., 45(1): 50-70.

Zeddam, J.L., P. Berrebi, F. Renaud, A. Raibaut and C. Gabrion. 1988. Characterization of two species of Lepeophtheirus (Copepoda: Caligidae) from flatfishes. Description of $L$. europaensis sp. nov. Parasitology, 96: 129-144.

Scient. ed.: J.M. Gili 